\title{
Assessing the growth potential and economic impact of the U.S. maple syrup industry
}

\author{
Michael L. Farrell, Department of Natural Resources, Cornell University ${ }^{a}$ * \\ Brian F. Chabot, Department of Ecology \& Evolutionary Biology, Cornell University ${ }^{\mathrm{b}}$
}

Submitted 29 May 2011 / Revised 5 August 2011 and 16 August 2011 / Accepted 26 August 2011 / Published online 27 March 2012

Citation: Farrell, M. L., \& Chabot, B. F. (2012). Assessing the growth potential and economic impact of the U.S. maple syrup

industry. Journal of Agriculture, Food Systems, and Community Development 2(2), 11-27.

http://dx.doi.org/10.5304/jafscd.2012.022.009

Copyright (C) 2012 by New Leaf Associates, Inc.

\begin{abstract}
This paper addresses the growth potential of the U.S. maple syrup industry. It outlines the number of potentially tappable maple trees and the economic impact of utilizing more of these trees for syrup production. U.S. producers currently tap $0.4 \%$ of all potentially tappable maple trees, with the highest percentage tapped in Vermont, at $2.94 \%$. Two scenarios are analyzed for how production and consumption could grow together: (1) if each state tapped $2.94 \%$ of its available trees and consumed all of the syrup locally among its residents; and (2) the number of taps needed in each state to provide 2.6 ounces $(76.9 \mathrm{ml})$ per person from "local" sources. Based on these

a, * Corresponding author: Michael L. Farrell, Department of Natural Resources, Cornell University, 157 Bear Cub Lane, Lake Placid, NY 12946 USA; +1-518-523-9337; mlf36@,cornell.edu

b Department of Ecology \& Evolutionary Biology, Cornell University, 102 Little Rice Hall, Ithaca, NY 14853 USA; +1-607-279-1291; bfc1@,cornell.edu

See the Cornell Maple Program website at http://maple.dnr.cornell.edu

analyses, states with the greatest potential to increase local production and consumption of pure maple syrup include Connecticut, Michigan, New York, Ohio, and Pennsylvania. Strategic marketing efforts are necessary to help maple producers take advantage of the growing demand for local, healthy, and organic food.

\section{Keywords}

economic impact, Forest Inventory \& Analysis (FIA), local food, maple syrup, red maple, sugar maple

\section{Introduction}

Maple syrup was once a much larger component of the rural economy in both the U.S. and Canada. The United States produced a record equivalent of $6,613,000$ gallons $(25,032,928$ liters $)$ of maple syrup in 1860 , with most of the syrup actually boiled down further to produce granulated maple sugar (U.S. Census Office, 1860). As seen in figure 1, maple production in the U.S. peaked in the 1800 s, steadily declined throughout the twentieth century, and is experiencing a rebirth in the twenty-first century. Maple production was always a small
\end{abstract}


Figure 1. Maple Syrup Production in the United States \& Canada 1860-2010

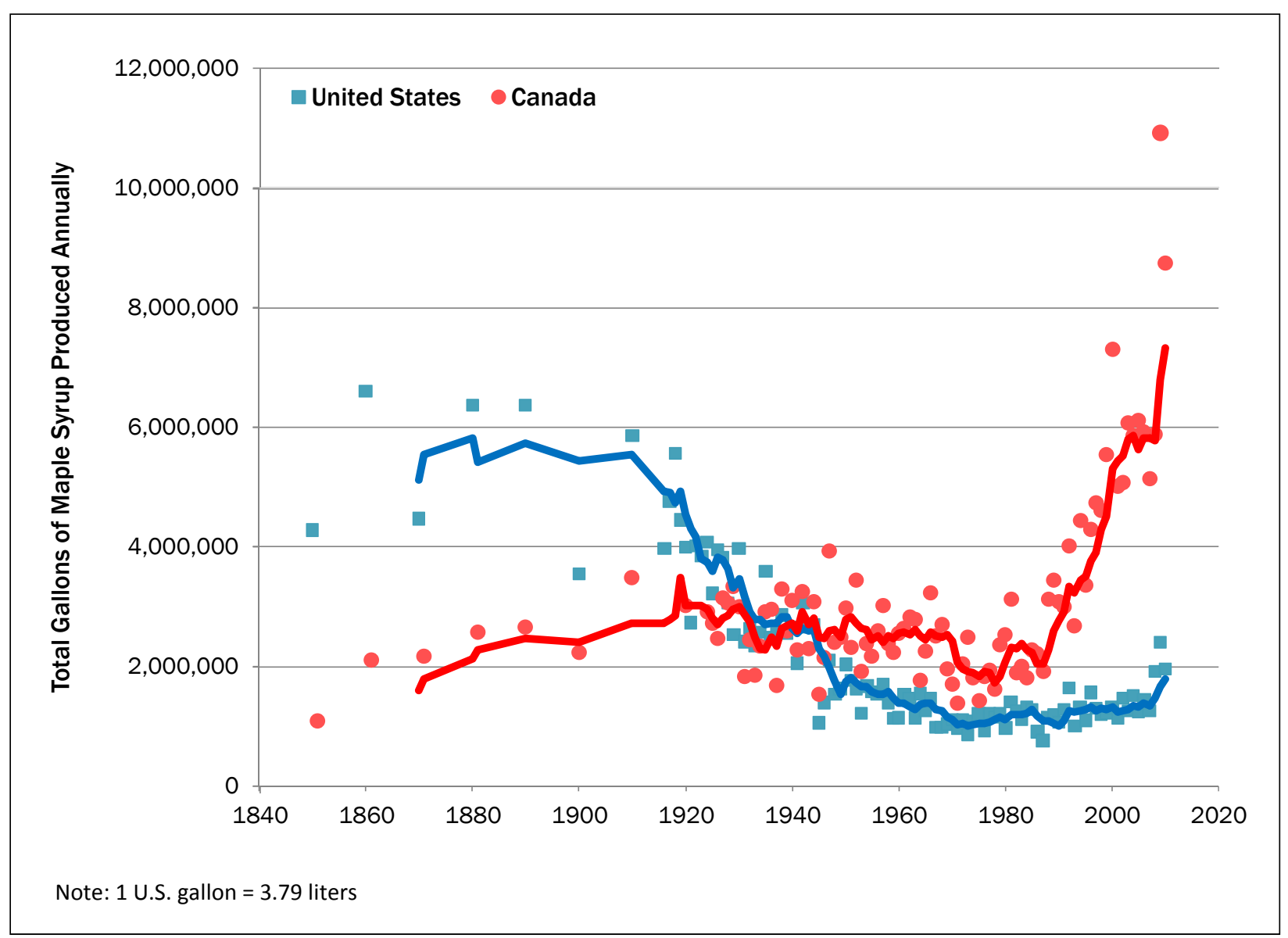

Sources: Statistics Canada. (2011, Dec. 14). Table 001-0008 - Production and farm value of maple products, annual (table). CANSIM (database) . Retrieved from

http://www5.statcan.gc.ca/cansim/a26?lang=eng\&retrLang=eng\&id=0010008\&pattern=maple\&tabMode=dataTable\&srchLan=$1 \& p 1=1 \& p 2=-1$

U.S. Department of Agriculture, Economic Research Service. (2011, June 10). Table 43-U.S. maple syrup production, imports, exports, and prices, by calendar year [Excel spreadsheet]. Retrieved from http://www.ers.usda.gov/briefing/sugar/data/table43.xls

component of the agricultural sector in Canada, but spiked dramatically in Quebec in the early 1980s. Producers installed vacuum tubing systems and reverse osmosis units that allowed them to significantly expand their operations while saving time and using less fuel. Production in Canada leveled off in recent years due to implementation of a quota system in Quebec in 2005 aimed at stabilizing prices and reducing surplus inventory (Gagné, 2008). Once the inventory was exhausted in 2008, prices rose to record levels, the quota restrictions were eased, and production levels surged once again.
Maple syrup is a luxury item consumed around the world, yet the greatest market for syrup still lies within the United States. The U.S. currently imports nearly four times as much syrup from Canada as it produces (Agriculture and Agri-Food Canada, 2006), so there is a tremendous opportunity for U.S. producers to expand production and fill domestic markets with "local" syrup. Maple syrup production is growing rapidly in the U.S., as a shortage of syrup and corresponding price increases led many sugarmakers to expand production and others to get started in recent years (Dravis, 2008; Dravis, 2009). Some politicians even seized on the opportunity to spur rural economic 
development through enhanced syrup production. Senator Charles Schumer (D-NY) introduced legislation in April 2008 that would provide grants and incentives to states in order to increase the number of trees being tapped on private lands (Churchill, 2008, Schwaner-Albright, 2009). This legislation was reintroduced in both the House and the Senate several times but has yet to pass in any form. Even without federal support, states including Connecticut, Maine, Michigan, New York, and Vermont have all moved forward with efforts to boost syrup production (Hoyum, 2010; Karkos, 2011; Litten,
2011; Wanamaker, 2009; Whitcomb, 2009).

Maple syrup consumption in the U.S. is only 2.6 oz. $(76.9 \mathrm{ml}) /$ person, yet this has grown tremendously over the past 35 years. Figure 2 tracks U.S. and Canadian syrup production, as well as U.S. imports and exports of maple syrup, from 1975 to 2009. Per capita consumption levels were determined by summing the amount of syrup produced by U.S. sugarmakers and the amount of syrup imported from Canada, subtracting the amount of syrup exported from the U.S., and then dividing by the population in a given year.

Figure 2. Maple Syrup Production, Imports and Exports in the United States and Canada, and Per Capita Annual Maple Syrup Consumption in the U.S. 1975-2009.

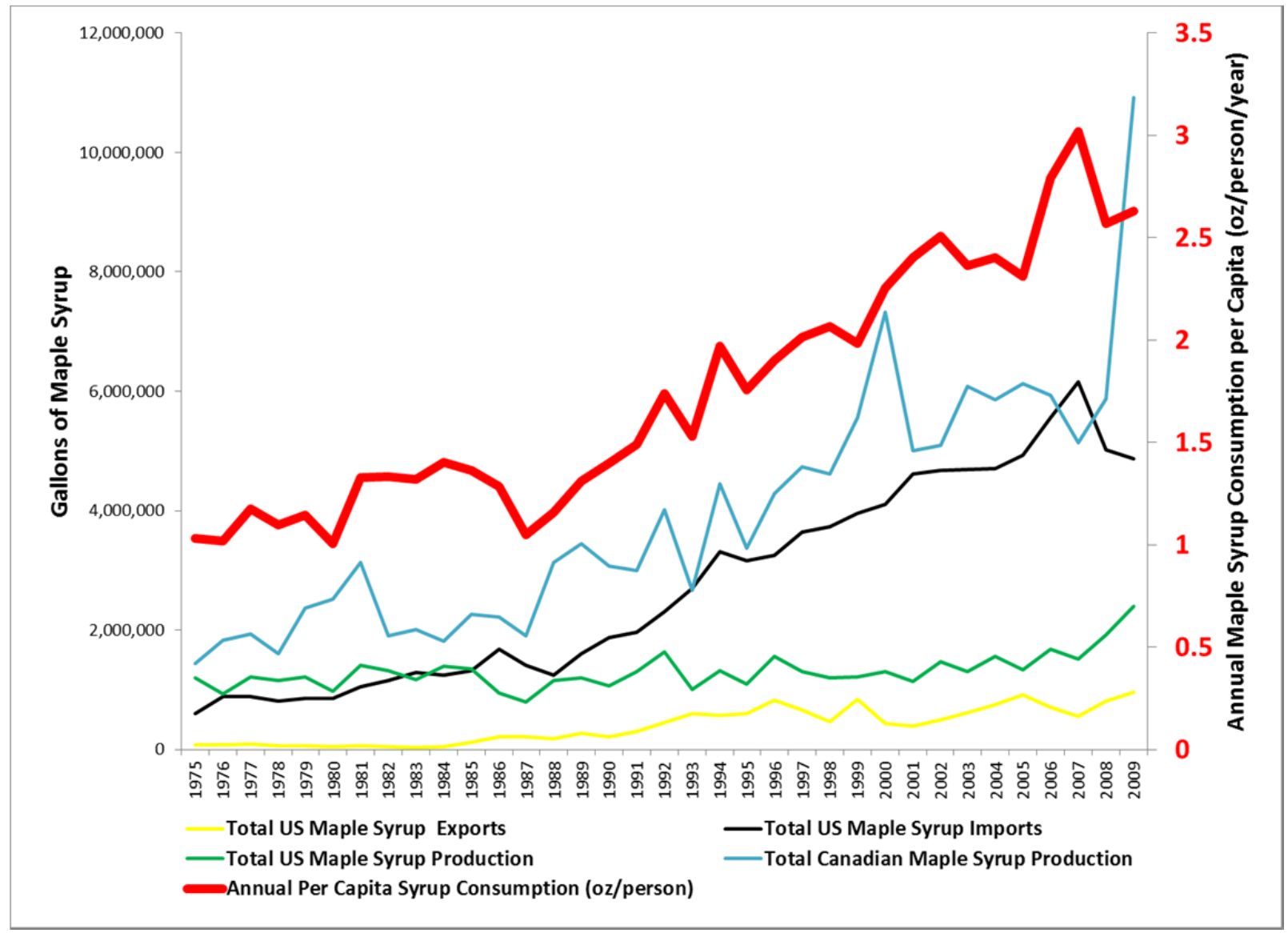

Sources: Statistics Canada. (2011, Dec. 14). Table 001-0008 - Production and farm value of maple products, annual (table). CANSIM (database) . Retrieved from http://www5.statcan.gc.ca/cansim/a26?lang=eng\&retrLang=eng\&id=0010008\&pattern=maple\& tabMode $=$ dataTable \&srchLan $=-1 \& \mathrm{p} 1=1 \& \mathrm{p} 2=-1$

U.S. Department of Agriculture, Economic Research Service. (2011, June 10). Table 43-U.S. maple syrup production, imports, exports, and prices, by calendar year [Excel spreadsheet]. Retrieved from http://www.ers.usda.gov/briefing/sugar/data/table43.xls U.S. Census Bureau. (2011, Dec. 21). Population estimates: State totals: Vintage 2011. Retrieved from http://www.census.gov/popest/data/state/totals/2011/index.html 
Per capita consumption of maple syrup in the U.S. has grown by $155 \%$ over the past 35 years, rising from 1.03 oz. (30.5 ml)/person in 1975 to $2.63 \mathrm{oz}$. $(77.8 \mathrm{ml}) /$ person in 2009. While the boost in U.S. consumption has been made possible by large increases in Canadian production, future levels of syrup production and consumption might not follow the same trends. Questions remain about where the additional syrup will be produced and consumed and the impact of future development on prices and profitability.

\section{Methods}

In order to determine the tapping potential in the U.S., analyses were performed using the latest U.S. Forest Service Forest Inventory \& Analysis (FIA) data (Bechtold \& Patterson, 2005) from 24 states that contain a significant number of sugar (Acer saccharum) and/or red maples (Acer rubrum). The number of potential taps was estimated by summing all of the sugar and red maple trees greater than 10" $(25.4 \mathrm{~cm})$ diameter at breast height (dbh) and applying conservative tapping guidelines of one tap for a $10 "-17 "(25.4-43.2 \mathrm{~cm})$ tree and 2 taps for trees $18 "(45.7 \mathrm{~cm})$ and greater. The FIA data are classified by ownership category (private, U.S. Forest Service, other federal land, and state and local government). They are also divided between the tappable (nonreserved) and nontappable (reserved) trees, as the reserved forestlands where timber production is legally prohibited are also likely to have restrictions on tapping.

To determine the percentage of potential taps that are actually utilized for syrup production, these figures were compared with the number of taps reported for each state in the 2010 National Agricultural Statistics Service (USDA NASS) Maple Syrup Crop Report. NASS only tracks maple syrup production for 10 states. Thus, although 14 additional states have a substantial number of maple trees, we lack any information on their number of taps and corresponding utilization rates. Syrup production levels in these states are currently so low that it is not feasible for NASS to gather these data.

Given the strong growth in the local food sector and the niche that maple syrup occupies as the local, minimally processed sugar alternative for the eastern U.S., analyses were performed to determine the market potential for maple syrup production and consumption on a "local" basis. For these analyses, local syrup is defined as being produced and consumed within the same state. Based on local production for local consumption, two scenarios are posed for how the maple industry could expand:

1. If each state tapped the same percentage of its trees that Vermont does and all of the syrup was consumed locally by the residents of the state, how much syrup must each person in that state consume on an annual basis?

2. Given that the average American consumes $2.6 \mathrm{oz} .(76.9 \mathrm{ml})$ of pure maple syrup annually, what percentage of the maple trees in each state would need to be tapped in order to fill the existing demand for syrup in a state from its own trees?

The final component of this paper is determining the economic impact for each of these two scenarios. For each state, average annual syrup production was estimated based on the average yield per tap in 2007-2009 for that state. For the states that do not have any production data, the lowest figure of all states, $22 \mathrm{oz}$. (651 ml)/tap for Pennsylvania, was assumed for the average production. A dollar figure was estimated by multiplying the possible production figures for each state by the average price that producers received in that state from retail, wholesale, and bulk syrup sales over the period 2007-2009. For states that do not have any data available, the average figure of USD37.10 per gallon for the entire U.S. was used.

\section{Results and Discussion}

As an agricultural crop, maple syrup production is unique since it is produced from large trees that are at least 30-40 years old. If a farmer or landowner would like to start producing syrup, he or she would either have to plant trees and wait a long time or find an established grove of maples that are 
already suitable for tapping. Thus, the immediate potential for syrup production is based on the existing resource of large maple trees. While sugar maples are the preferred species for tapping due to the high sugar concentration in their sap, red maples are also suitable for syrup production, but usually exhibit slightly lower sap sugar production than sugar maples (Chapeskie, Wilmot, Chabot, \& Perkins, 2006). The number of potential sugar maple taps is displayed in figure 3 , while the number of potential red maple taps can be seen in figure 4. Figure 5 presents the total number of combined sugar and red maple taps for 24 states.

Michigan contains the greatest number of potential sugar maple taps, whereas Pennsylvania leads in red maples. When considering sugar and red maples combined, New York has the most potentially tappable trees of any state. The more southern and western states tend to have more red maple than sugar maple potential taps, though there are exceptions to this rule. For instance, Connecticut, Maine, Massachusetts, and Pennsylvania all have significantly more red maples than sugar maples, whereas Illinois, Indiana and Kentucky all have more sugar than red maple potential taps. Although Vermont dominates in syrup production, it ranks fifth in the number of potential sugar maple taps and seventh in the combined total number of sugar and red maple potential taps. Producers in Vermont make up for this apparent shortfall by tapping a much larger percentage of their trees than any other state.

Figure 3. Number of Potential Sugar Maple Taps for 19 States by Ownership Status, 2011

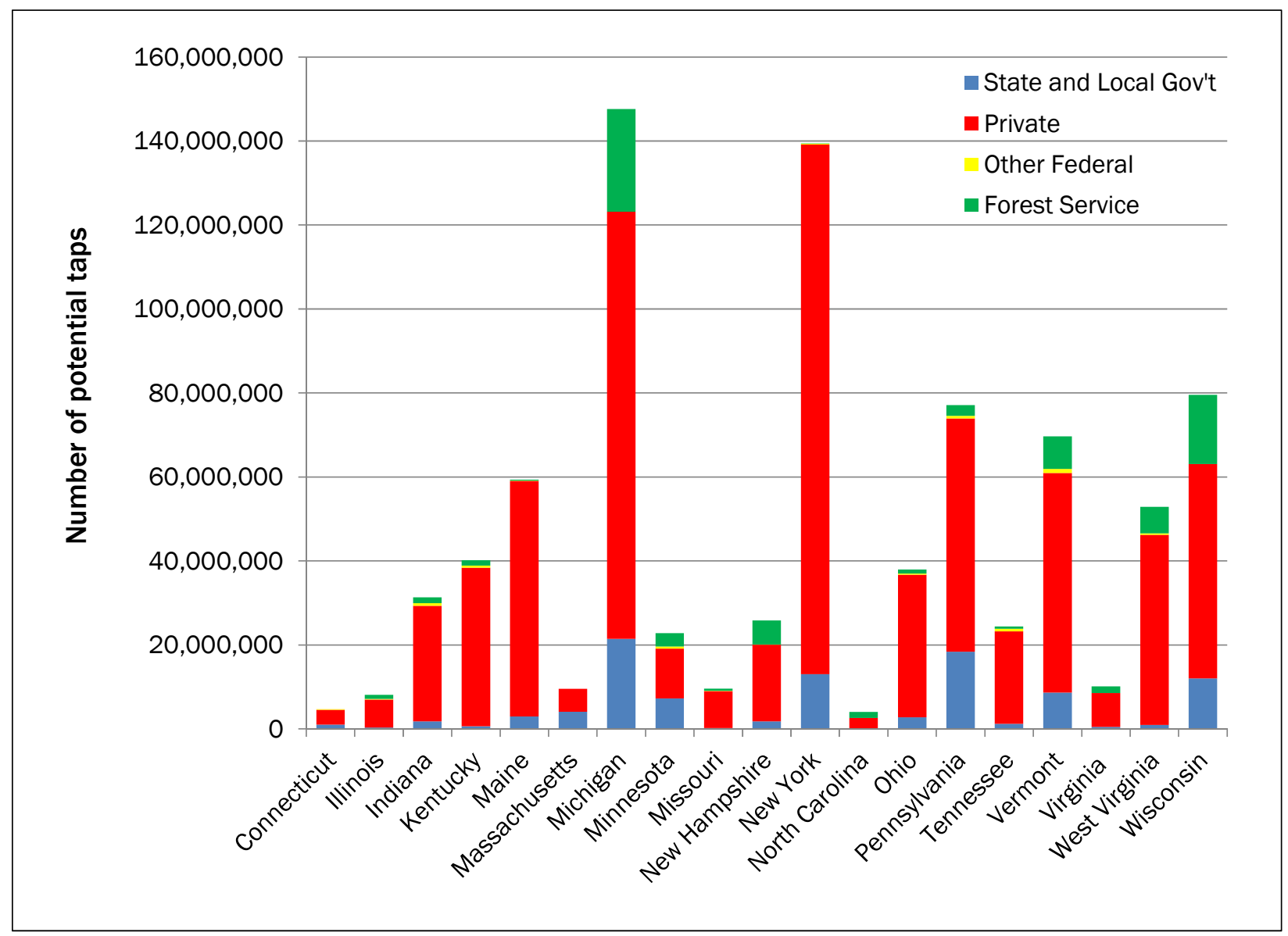

Source: U.S. Department of Agriculture, Forest Service. (2010).. 
It is important to realize that the figures presented here overestimate the realistic tapping potential for several reasons. In order to economically tap maples, the trees must be located close enough to an access road and the density of trees must be high enough to justify installing a tubing or road system to collect the sap. While the FIA data includes all sugar and red maple trees growing on nonreserved forestland (land that is not restricted from management), many of these trees are growing in locations that are not suitable for tapping. Some of them are in stands that have a low density of maples, are too far from an access road, or are otherwise inaccessible due to topographic constraints. Further research is in process to obtain a more realistic estimate of the tapping potential for several states based on these considerations.
Finally, it is important to note that the FIA program only deals with forestland, and therefore does not account for a significant percentage of the trees that are actually tapped. Maples growing in yards, parks, and along roads are favored by producers who collect with buckets due to the easy access and large volumes of sweet sap they generate. In order to quantify these potential taps, much more detailed inventory data must be collected and analyzed through urban and community forestry research initiatives.

\section{Utilization of the Maple Resource for Syrup Production}

Significant differences exist in the utilization of the maple resource for syrup production, as seen in figure 6 . Vermont clearly dominates the industry

Figure 4. Number of Potential Red Maple Taps for 24 States by Ownership Status, 2011

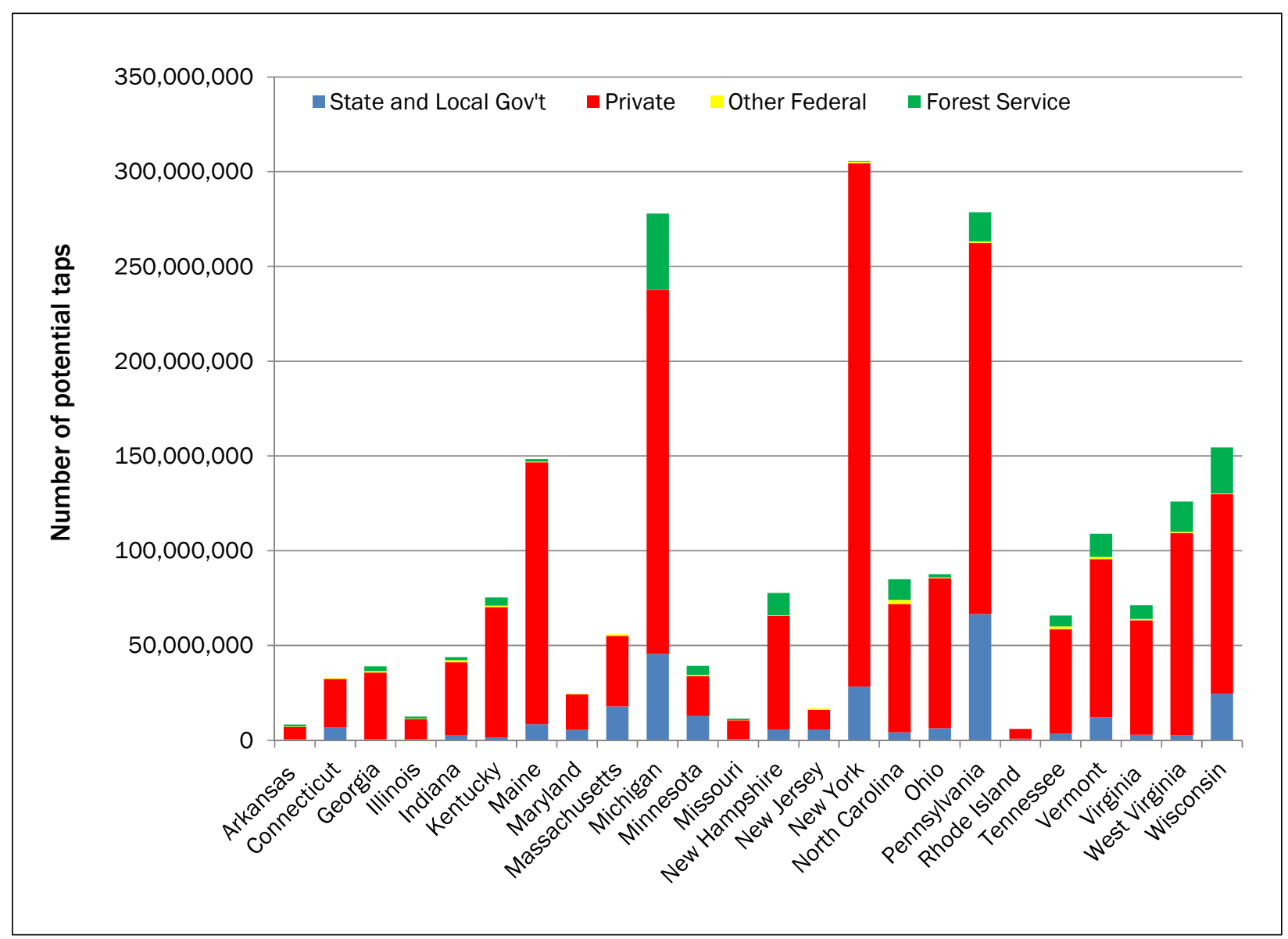

Source: U.S. Department of Agriculture, Forest Service. (2010). 
due to its relatively high utilization rate of $2.94 \%$, whereas states such as Michigan $(0.15 \%)$, New York $(0.45 \%)$, and Pennsylvania $(0.17 \%)$ have tremendous potential for expansion. Although these three states have the largest maple resource, they tap a much lower percentage of their trees than Vermont does.

The discrepancies in utilization rates can largely be explained by cultural traditions (Hinrichs, 1998). When there are strong cultural norms to produce maple syrup in a certain area, farmers and landowners are more likely to do so. However, even when there is a robust maple resource, if nobody is already producing syrup, then it is much less likely that landowners start production. Thus, even though Michigan contains the most tappable sugar maples of any state, the logging industry has dominated the landscape and only $0.15 \%$ of the maples are used for syrup production. Similarly, West Virginia has more tappable maple trees than Vermont, yet the culture for syrup production does not exist in most of the state. Even though Vermont ranks seventh in the number of potential taps, it ranks first in syrup production due in large part to the strong cultural traditions and superior branding and marketing of its product over the last century.

Among the more southerly states, such as Kentucky and Tennessee, even though maples grow abundantly, the climate is not thought to be as suitable for commercial syrup production. The climate may play a critical role in explaining why

Figure 5. Total Number of Potential Sugar and Red Maple Taps for 24 States in the United States, 2011

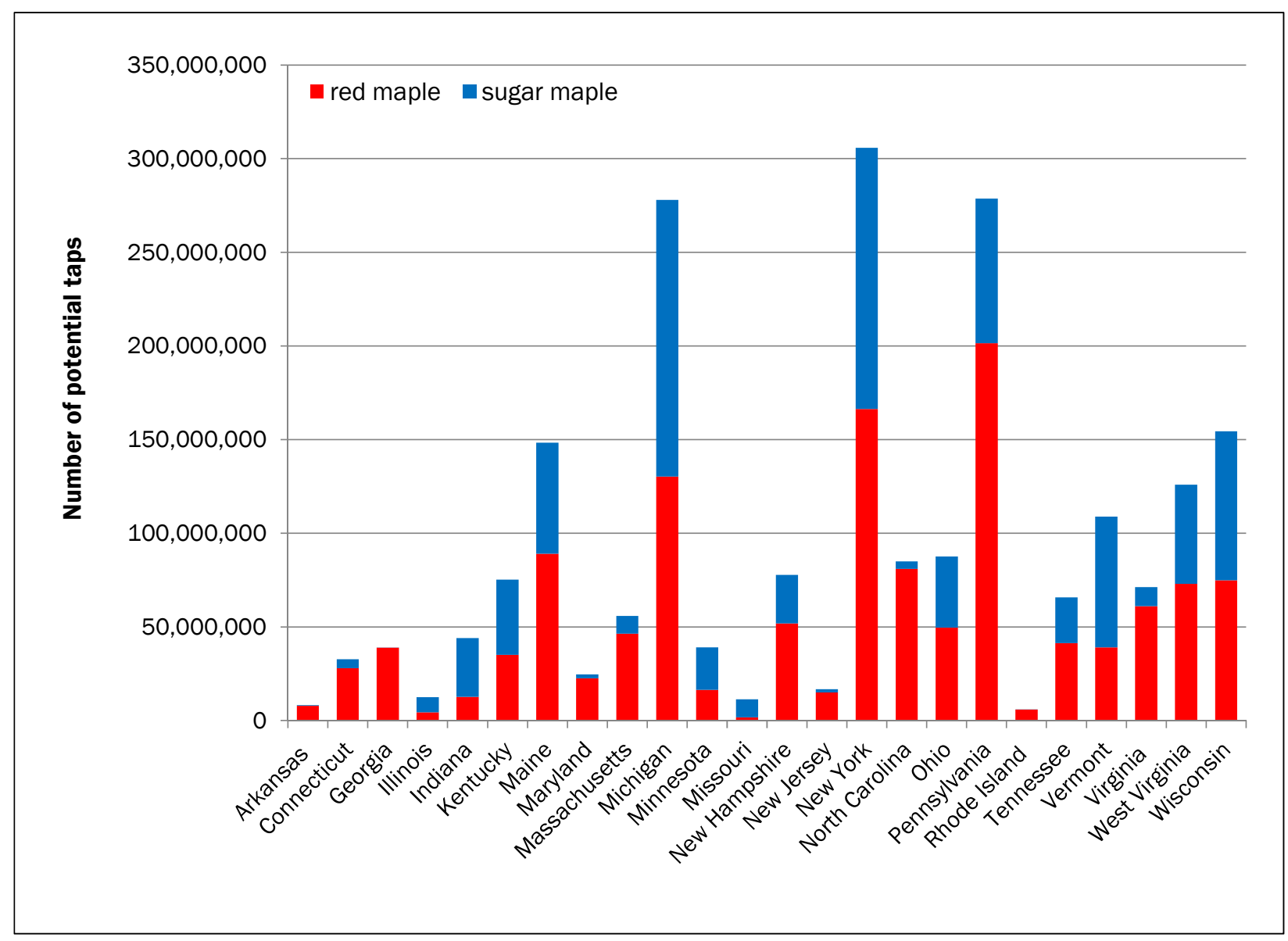

Source: U.S. Department of Agriculture, Forest Service. (2010). 
more syrup is not currently produced in these states and what the potential for increasing production is. Sugaring used to be more commonplace in the mid-Atlantic region during the 1800s (U.S. Census, 1860), but that tradition has been lost over time. In these states, the limited number of freezing nights and the spells of very warm weather can cause tapholes to "dry up" prematurely, especially when using buckets or gravity-based tubing to collect the sap. However, with new technologies and techniques, such as high-vacuum tubing, check-valve spout adapters, and replacement of droplines and spouts every year, there may be opportunities to achieve economic returns from syrup production even when the weather is not favorable. More research is needed to determine the potential yields in warmer climates using modern sap-collection technologies. This could provide immediate economic development in these states, while providing a preview for what the Northeast can expect in a future climate that is predicted to be similar to the mid-Atlantic region (Skinner, DeGaetano, \& Chabot, 2010).

Finally, it should be noted that the NASS estimates are based on voluntary reporting of producers. Many sugarmakers are opposed to a government agency knowing about their activities and therefore do not provide NASS with accurate (or any) information on their production levels. Thus, even though NASS provides the most comprehensive database on syrup production in the U.S., using these figures likely underestimates the actual production in many states. Furthermore, since NASS only tracks syrup production in 10 states, there is no data on the limited amount of sugaring that takes place in the other states.

Figure 6. Utilization of the Maple Resource for Syrup Production, 2011

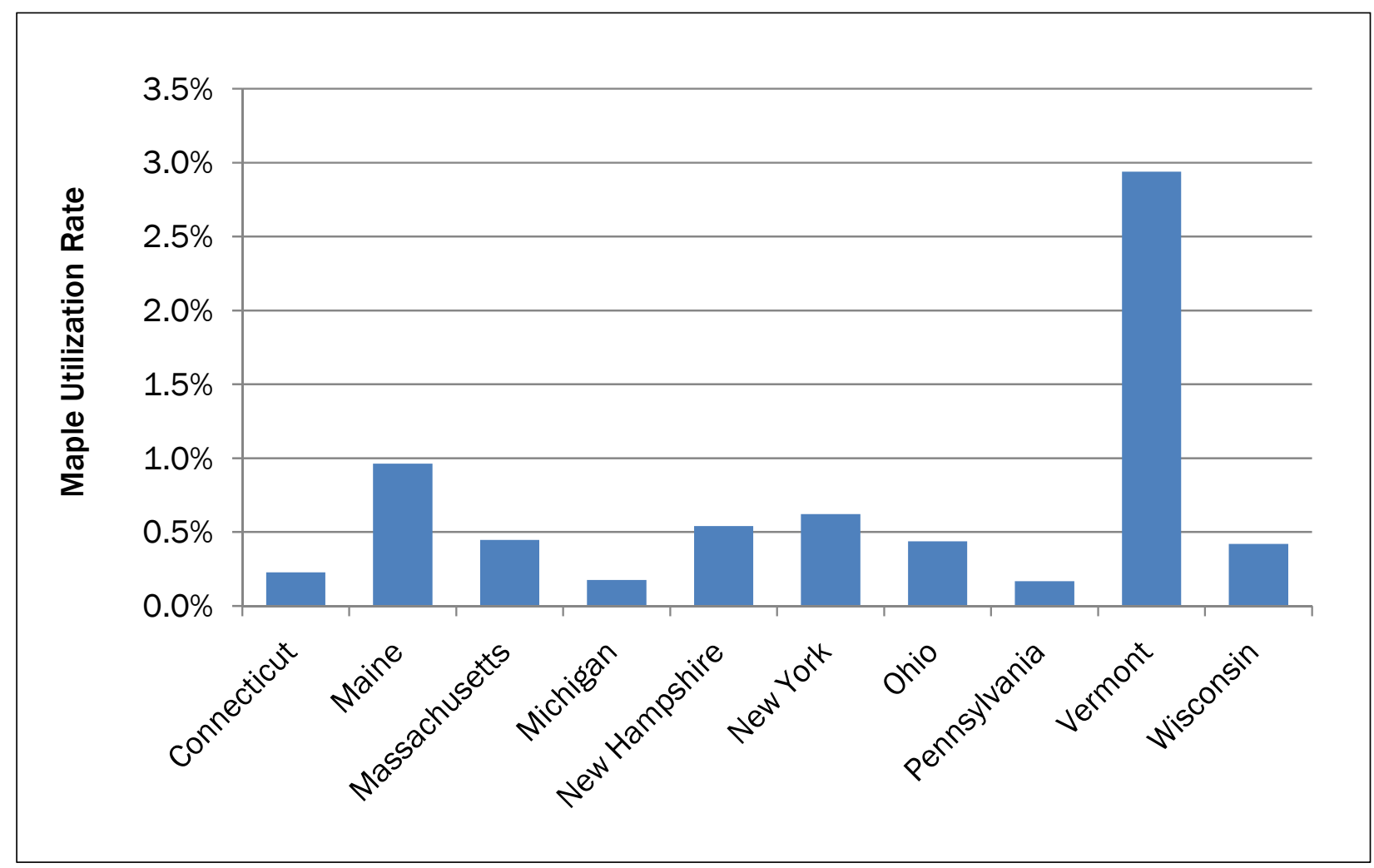

Note: Results based on NASS Maple Syrup Crop Report (2010) and U.S. Foresty Service FIA data (2010) on the number of tappable sugar and red maple trees. 
Economic Impact of Increased Syrup Production: Two Scenarios for Local Consumption

This section presents the results of two scenarios for increasing the production of maple syrup through local consumption within the state in which it is produced. The first scenario examines what could happen if each state tapped the same percentage of its trees as Vermont does, while the second scenario estimates the number of taps needed to provide each resident with 2.6 oz. (76.9 $\mathrm{ml}$ ) of locally produced syrup.

\section{Scenario 1: What if Each State Tapped the Same} Percentage of Its Trees as Vermont

The first scenario provides a theoretical upper limit for what is possible to achieve in each state. Although no other state will likely ever tap the same percentage of its trees as Vermont does, this analysis presents the economic impact and per capita consumption levels necessary to consume all of the syrup locally if it did.

There are interesting observations when examining the per capita consumption necessary to sell all of the syrup produced in a state among the residents of that state. While most states have low "necessary" consumption levels, below 3 oz./person, the residents of Vermont and Maine would need to consume significantly more syrup, at 180.9 oz. $(5,349.9 \mathrm{ml})$ per person and $26.6 \mathrm{oz}$. $(786.7 \mathrm{ml})$ per person, respectively, in order to utilize all of the syrup they produce themselves. These extremely high values result from the combination of extensive syrup production and relatively low populations. While it is likely that many producers of maple syrup consume at least 180 ounces themselves in a given year, it would take enormous marketing efforts and a tremendous reduction in prices to encourage all citizens to consume this much pure maple syrup annually.

Given this reality, Vermont and Maine have not limited their markets to the residents of their own state, but strategically looked elsewhere to sell most of their syrup. Vermont made wise decisions throughout the twentieth century in branding itself as the maple state in order to export this high-value crop throughout the U.S. and now to the world.
Similarly, Canada purposefully built a worldwide image as the maple syrup nation and now exports over $80 \%$ of its production (Agriculture and Agri-Food Canada, 2006). It's commonly known within the maple industry that the vast majority of syrup production in Maine is carried out by Canadian citizens on former paper company land along the Quebec border. Since this region has few people to sell to locally, nearly all of the syrup is sold in bulk to the major packaging and distribution companies in the U.S. and Canada.

Although exports will continue to be important for agricultural commodities, the local food sector is currently experiencing rapid growth. It is now even being embraced by Walmart, which plans to source a larger percentage of the produce sold in its stores from farmers located in that state (Clifford, 2010). In order to examine the potential for local syrup consumption on a statewide basis, table 1 presents two figures:

1. The per capita syrup consumption necessary to consume all of the syrup currently produced in a state locally, and

2. The syrup consumption levels necessary if a state tapped the same percentage of its trees as Vermont does.

There are states such as Illinois, Missouri, and New Jersey that have high populations and relatively few tappable maple trees. Sugarmakers in these states do not produce enough syrup to be counted by NASS, but if they tapped $2.94 \%$ of their trees (as Vermont does), the average person would only have to consume less than $2 \mathrm{oz}$. (59 ml) annually to exhaust the supply. Therefore, these states could aggressively grow their maple industries and market exclusively through local outlets without trying to compete in the greater marketplace. As evidence, researchers in Illinois have examined the economic feasibility of expanding syrup production in their state and found promising results (Buchheit, Carver, Zaczek, Crum, Mangun, Williard, \& Preece, 2004). States with high populations and a slightly greater number of tappable trees, such as Indiana, Kentucky, Massachusetts, Ohio, Tennessee, and 
Table 1. The Economic Impact of Increasing Syrup Production Levels to those Achieved in Vermont (all prices in USD)

\begin{tabular}{|c|c|c|c|c|c|c|c|c|c|c|c|}
\hline & $\begin{array}{l}\text { Population } \\
\text { (2010 } \\
\text { Census Data) }\end{array}$ & $\begin{array}{l}\text { Number of } \\
\text { Potential } \\
\text { Taps }^{1}\end{array}$ & $\begin{array}{l}\text { Number of } \\
\text { Actual } \\
\text { Taps }^{2}\end{array}$ & $\begin{array}{l}\text { Number of Taps } \\
\text { When Achieving } \\
\text { Vermont's } \\
\text { Utilization Rate }{ }^{3}\end{array}$ & $\begin{array}{l}\text { Syrup } \\
\text { Production } \\
\text { Efficiency } \\
\text { (oz/tap) }\end{array}$ & $\begin{array}{c}\text { Local per-Capita } \\
\text { Consumption at } \\
\text { current } \\
\text { utilization rates } \\
\text { (oz./person) }\end{array}$ & $\begin{array}{c}\text { Local per-capita } \\
\text { consumption at } \\
\text { Vermont } \\
\text { utilization rates } \\
\text { (oz./person) }\end{array}$ & $\begin{array}{l}\text { Average } \\
\text { Price } \\
\text { per Gallon }\end{array}$ & $\begin{array}{l}\text { Current Value } \\
\text { of Syrup } \\
\text { Production }\end{array}$ & $\begin{array}{l}\text { Potential Value of } \\
\text { Syrup Production } \\
\text { at Vermont's } \\
\text { Utilization Rates }\end{array}$ & $\begin{array}{l}\text { Economic Impact of } \\
\text { Increasing Syrup } \\
\text { Production to } \\
\text { Vermont's Level }\end{array}$ \\
\hline Arkansas & $2,915,918$ & $8,293,520$ & - & 243,745 & 22.4 & 0.0 & 1.9 & $\$ 37.80$ & - & $\$ 1,612,373$ & $\$ 1,612,373$ \\
\hline Connecticut & $3,574,097$ & $32,702,898$ & 75,000 & 961,132 & 23.7 & 0.5 & 6.4 & $\$ 59.23$ & $\$ 823,343$ & $\$ 10,551,221$ & $\$ 9,727,878$ \\
\hline Georgia & $9,687,653$ & $38,954,859$ & - & $1,144,876$ & 22.4 & 0.0 & 2.6 & $\$ 37.80$ & - & $\$ 7,573,354$ & $\$ 7,573,354$ \\
\hline Illinois & $12,830,632$ & $12,527,570$ & - & 368,183 & 22.4 & 0.0 & 0.6 & $\$ 37.80$ & - & $\$ 2,435,530$ & $\$ 2,435,530$ \\
\hline Indiana & $6,483,802$ & 43,971,137 & - & $1,292,303$ & 22.4 & 0.0 & 4.5 & $\$ 37.80$ & - & $\$ 8,548,587$ & $\$ 8,548,587$ \\
\hline Kentucky & $4,339,367$ & $75,286,754$ & - & $2,212,663$ & 22.4 & 0.0 & 11.4 & $\$ 37.80$ & - & $\$ 14,636,768$ & $\$ 14,636,768$ \\
\hline Maine & $1,328,361$ & $148,404,616$ & $1,430,000$ & $4,361,583$ & 27.9 & 30.0 & 91.5 & $\$ 33.27$ & $\$ 10,354,694$ & $\$ 31,582,419$ & $\$ 21,227,726$ \\
\hline Maryland & $5,773,552$ & $24,643,818$ & - & 724,277 & 22.4 & 0.0 & 2.8 & $\$ 37.80$ & - & $\$ 4,791,093$ & $\$ 4,791,093$ \\
\hline Massachusetts & $6,547,629$ & $55,928,669$ & 250,000 & $1,643,733$ & 24.6 & 0.9 & 6.2 & $\$ 48.73$ & $\$ 2,339,200$ & $\$ 15,380,080$ & $\$ 13,040,880$ \\
\hline Michigan & $9,883,640$ & $277,960,651$ & 490,000 & $8,169,211$ & 29.1 & 1.4 & 24.1 & $\$ 42.53$ & $\$ 4,737,930$ & $\$ 78,990,094$ & $\$ 74,252,164$ \\
\hline Minnesota & $5,303,925$ & 39,181,626 & - & $1,151,541$ & 22.4 & 0.0 & 4.9 & $\$ 37.80$ & - & $\$ 7,617,440$ & $\$ 7,617,440$ \\
\hline Missouri & $5,988,927$ & $11,322,763$ & - & 332,774 & 22.4 & 0.0 & 1.2 & $\$ 37.80$ & - & $\$ 2,201,299$ & $\$ 2,201,299$ \\
\hline New Hampshire & $1,316,470$ & $77,720,574$ & 420,000 & $2,284,193$ & 29.5 & 9.4 & 51.2 & $\$ 50.40$ & $\$ 4,882,752$ & $\$ 26,555,112$ & $\$ 21,672,360$ \\
\hline New Jersey & $8,791,894$ & $16,806,386$ & - & 493,936 & 22.4 & 0.0 & 1.3 & $\$ 37.80$ & - & $\$ 3,267,390$ & $\$ 3,267,390$ \\
\hline New York & $19,378,102$ & 305,685,731 & $1,903,000$ & $8,984,045$ & 26.9 & 2.6 & 12.5 & $\$ 38.83$ & $\$ 15,543,598$ & $\$ 73,381,184$ & $\$ 57,837,585$ \\
\hline North Carolina & $9,535,483$ & $84,977,529$ & - & $2,497,473$ & 22.4 & 0.0 & 5.9 & $\$ 37.80$ & - & $\$ 16,520,786$ & $\$ 16,520,786$ \\
\hline Ohio & $11,536,504$ & $87,616,491$ & 385,000 & $2,575,032$ & 29.7 & 1.0 & 6.6 & $\$ 39.07$ & $\$ 3,484,421$ & $\$ 23,305,184$ & $\$ 19,820,763$ \\
\hline Pennsylvania & $12,702,379$ & 278,622,099 & 465,000 & $8,188,650$ & 22.4 & 0.8 & 14.4 & $\$ 36.00$ & $\$ 2,929,500$ & $\$ 51,588,498$ & $\$ 48,658,998$ \\
\hline Rhode Island & $1,052,567$ & $6,019,295$ & - & 176,906 & 22.4 & 0.0 & 3.8 & $\$ 37.80$ & - & $\$ 1,170,233$ & $\$ 1,170,233$ \\
\hline Tennessee & $6,346,105$ & $65,814,848$ & - & $1,934,286$ & 22.4 & 0.0 & 6.8 & $\$ 37.80$ & - & $\$ 12,795,301$ & $\$ 12,795,301$ \\
\hline Vermont & 625,741 & $108,881,278$ & $3,200,000$ & $3,200,000$ & 35.4 & 180.9 & 180.9 & $\$ 34.57$ & $\$ 30,566,151$ & $\$ 30,566,151$ & - \\
\hline Virginia & $8,001,024$ & $71,216,930$ & - & $2,093,052$ & 22.4 & 0.0 & 5.9 & $\$ 37.80$ & - & $\$ 13,845,539$ & $\$ 13,845,539$ \\
\hline West Virginia & $1,852,994$ & $125,961,220$ & - & $3,701,976$ & 22.4 & 0.0 & 44.8 & $\$ 37.80$ & - & $\$ 24,488,573$ & $\$ 24,488,573$ \\
\hline Wisconsin & $5,686,986$ & 154,493,465 & 650,000 & $4,540,533$ & 30.8 & 3.5 & 24.6 & $\$ 37.17$ & $\$ 5,806,053$ & $\$ 40,557,811$ & $\$ 34,751,758$ \\
\hline United States & $308,745,538$ & $2,152,994,723$ & $9,268,000$ & $63,276,105$ & 24.7 & 0.7 & 5.1 & $\$ 39.54$ & $\$ 81,467,642$ & $\$ 503,962,019$ & $\$ 422,494,377$ \\
\hline
\end{tabular}

${ }_{1}^{1}$ These are calculated only for nonreserved forestlands, i.e., those that are NOT legally prohibited from timber harvesting or management.

2 Based on USDA NASS 2010 Maple Syrup Crop Report.

${ }^{3}$ These figures are calculated by multiplying the number of potential taps by $2.94 \%$, the utilization rate achieved in Vermont.

Based on the average production per tap for each state for 2007-2009 as seen in the 2010 NASS Maple Syrup Crop Report.

${ }^{5}$ Based on the average price received for all retail, wholesale, and bulk syrup sales for each state for 2007-2009 as seen in the 2010 NASS Maple Syrup Crop Report. 
Virginia could also expand production aggressively. The per capita consumption levels necessary in these states range from $4.5 \mathrm{oz} .(133.1 \mathrm{ml})$ to $6.6 \mathrm{oz}$. $(195.2 \mathrm{ml})$ per person, which are certainly achievable levels, especially if any efforts are put into marketing local syrup to each state's citizens and businesses.

There are other states that have large populations and a much greater resource of tappable maple trees, such as Michigan, New York, Pennsylvania, and Wisconsin. If these states were to expand to the same levels as Vermont, the consumption levels needed to sell all the syrup locally would be much higher, between $14 \mathrm{oz}$. (414 ml) and $25 \mathrm{oz}$. $(739 \mathrm{ml})$ per person. Since it would be more difficult to sell all of the additional syrup locally, producers in these states would have to sell some of their syrup in barrels to large packaging companies. Bulk prices are strongly tied to global supply and demand, which is out of the control of individual producers. Therefore these states may not be able to expand as aggressively if global demand does not keep pace with supply, and prices fall to unprofitable levels.

Finally, states such as Vermont and Maine already produce much more syrup than can realistically be consumed locally. The majority of their syrup is already sold in bulk to large bottling companies, whose success is highly dependent on the national and global markets for maple syrup. Whereas the local food movement will help some of these producers sell their syrup to nearby residents and visitors, the dominant outlets for most of the syrup produced will continue to be elsewhere. Thus, expansion in these states will likely be curtailed if production outpaces consumption and bulk syrup prices fall.

Under the hypothetical scenario in which each state taps the same percentage of its trees as Vermont currently does, the U.S. maple industry could grow from approximately USD81 million to over USD500 million annually. It is important to realize that only $24 \%$ of total U.S. residents live in the 11 major maple producing states, while $52 \%$ live in the 25 states that contain a significant number of sugar and red maple trees. Thus, roughly half of U.S. citizens will not have access to local syrup and must purchase it from other states or Canada. At current production levels, if U.S. residents only consumed maple syrup produced within the U.S., the average per capita consumption would be 0.7 oz. $(20.7 \mathrm{ml})$, much less than the current figure of 2.6 oz. $(76.9 \mathrm{ml})$. If the U.S. were to develop its maple industry in every state the way Vermont has, did not import any syrup from Canada nor export any throughout the world, the average consumption would have to increase to $5.1 \mathrm{oz}$. (150.8 ml) per person. Given that this figure is less than the per capita consumption in Quebec, it is not an unreasonable proposition. However, as previously stated, it is highly unlikely that any state could achieve the same levels of production as Vermont, let alone every state. Furthermore, barring any unforeseen and extraordinary political tensions or drastic fluctuations in the exchange rate with Canada, the U.S. will continue to import the majority of its syrup from Quebec. Thus, although the U.S. will likely increase its production and consumption of pure maple syrup, it will probably never achieve the levels as conjectured in table 1.

\section{Scenario 2: What if Each State Produced All the Syrup its Residents Consume Locally}

Whereas scenario 1 examines the increased consumption necessary for each state to tap the same percentage of its trees that Vermont does, scenario 2 assumes that per capita consumption levels will stay the same, yet all of the syrup will come from local sources. This scenario provides a more realistic target for many states to achieve. It calculates the number of taps necessary, the corresponding utilization rate, and economic impact for each state to provide $2.6 \mathrm{oz}$. $(76.9 \mathrm{ml})$ of maple syrup to each of its residents (see table 2). The same assumptions on production per tap and price per gallon of syrup are used for this analysis.

Vermont and Maine would only need 45,996 and 123,962 taps, respectively, to supply all of their citizens with $2.6 \mathrm{oz}$. $(76.9 \mathrm{ml})$ of syrup. Since there are many large producers and such low populations in these states, most of the syrup in Vermont and Maine is sold in bulk to large bottling companies 
and shipped out of state. Thus, the average price per gallon received by producers is the lowest in Vermont and Maine, at USD34.57 and USD33.27, respectively. New Hampshire, New York, and Wisconsin are the only other states that currently have more taps than needed to provide their residents with $2.6 \mathrm{oz}$. $(76.9 \mathrm{ml})$ of syrup each year.

On the opposite end of the spectrum, there are states with large populations and a limited maple resource that would have a difficult time trying to provide each of their residents with $2.6 \mathrm{oz}$. (76.9 $\mathrm{ml}$ ) of syrup. The necessary utilization rates in New Jersey and Missouri at $6.1 \%$ and Illinois at $11.9 \%$ are beyond the levels that could reasonably be expected to be achieved. Thus these states must continue to rely on imported syrup to meet consumer demand. Individual producers in these states would have a difficult time just supplying their own customer base with syrup and therefore would have to purchase bulk syrup from other states in order to meet local market demand. This strategy is already practiced throughout the maple industry, creating better synergy between the large sugarmakers who are focused on production and the smaller sugarmakers who concentrate on the marketing of finished products.

There are several states that could easily develop their maple industries further by supplying the local markets for pure maple products. Connecticut, Massachusetts, Michigan, Ohio, and Pennsylvania all have existing maple industries and the infrastructure in place to spur additional development. With existing utilization rates ranging between $0.15 \%$ and $0.45 \%$, these states would only need to tap at most $1.2 \%$ of their trees to supply 2.6 oz. $(76.9 \mathrm{ml})$ of local syrup to their residents. Particularly desirable places for expansion are states such as Connecticut that have an affluent population with a strong desire to purchase local food. Expanding production in these regions is one of the best ways to assure profitability for producers. As evidence, producers in Connecticut sell most of their syrup retail and therefore command the highest average price of any state at USD59.23/gallon.
New York has the greatest number of potential taps, the largest population of any maple-producing state, and an extensive educational infrastructure already in place to enhance development. The industry has been growing in recent years and is poised for further expansion. Its utilization rate of $0.62 \%$ just barely allows the state to supply all residents with $2.6 \mathrm{oz}$. $(76.9 \mathrm{ml})$ of syrup. However, previous studies have found that most of the syrup consumed in New York is purchased at grocery stores and comes from out of state (for example, see Chamberlin, 2008). New York is also a net importer of bulk maple syrup, as more bulk syrup is bought in and repackaged by individual producers than is sold out of state (Farrell \& Stedman, 2009). Thus, per capita consumption in New York is already well above $2.6 \mathrm{oz} .(76.9 \mathrm{ml})$ per person, but much more research is needed to determine the actual figure. New York state government officials have recognized the opportunity to increase maple production and have made several investments to help expand the industry, including creating a Maple Task Force in 2009 to explore the ways in which the state can assist in developing the maple industry (Wanamaker, 2009).

Generally speaking, most states would only have to tap a small percentage of their trees in order to supply their residents with local maple syrup. Eight states would have rates below $1 \%$ and another 8 states would have rates between $1 \%$ and $2 \%$. Although these are feasible goals, it will be more difficult to establish maple production in regions that do not currently have a significant maple industry. For instance, although states such as Kentucky, Virginia, and West Virginia have a robust maple resource and some syrup producers already exist, the educational and cultural infrastructure simply does not exist to adequately develop the maple industry at this time. Since the climate is also much warmer in these states than in the traditional producing regions, there will be skeptics who believe that syrup production is only supposed to occur in northern states. Much more research is necessary to determine what yields one could expect utilizing various sap collection 
Table 2. Economic Impact of Producing All of the Maple Syrup Consumed in a State Locally (all prices in USD)

\begin{tabular}{|c|c|c|c|c|c|c|c|c|c|c|c|}
\hline & $\begin{array}{l}\text { Population } \\
\text { (2010 } \\
\text { Census Data) }\end{array}$ & $\begin{array}{l}\text { Number of } \\
\text { Potential } \\
\text { Taps }\end{array}$ & $\begin{array}{l}\text { Number of } \\
\text { Actual } \\
\text { Taps }\end{array}$ & $\begin{array}{l}\text { Number of Taps } \\
\text { Necessary To } \\
\text { Provide 2.6 oz/ } \\
\text { Resident of } \\
\text { Each State }^{1}\end{array}$ & $\begin{array}{l}\text { Current } \\
\text { Utilization } \\
\text { Rate }^{2}\end{array}$ & $\begin{array}{l}\text { Utilization Rate } \\
\text { Necessary to } \\
\text { provide } 2.6 \\
\text { oz/resident of each } \\
\text { state }^{3}\end{array}$ & $\begin{array}{l}\text { Syrup } \\
\text { Production } \\
\text { Efficiency } \\
\text { (oz/tap) }\end{array}$ & $\begin{array}{l}\text { Average } \\
\text { Price per } \\
\text { Gallon }\end{array}$ & $\begin{array}{l}\text { Current Value } \\
\text { of Syrup } \\
\text { Production }\end{array}$ & $\begin{array}{l}\text { Potential Value of } \\
\text { Syrup Production to } \\
\text { Supply } 2.6 \text { oz for Each } \\
\text { State Resident }\end{array}$ & $\begin{array}{l}\text { Economic Impact } \\
\text { of Supplying } 2.6 \\
\text { oz/Resident for } \\
\text { Each State }\end{array}$ \\
\hline Arkansas & $2,915,918$ & $8,293,520$ & - & 338,455 & - & $4.08 \%$ & 22.4 & $\$ 37.80$ & - & $\$ 2,238,878$ & $\$ 2,238,878$ \\
\hline Connecticut & $3,574,097$ & $32,702,898$ & 75,000 & 391,720 & $0.23 \%$ & 1.20 & 23.7 & $\$ 59.23$ & $\$ 823,343$ & $\$ 4,300,272$ & $\$ 3,476,928$ \\
\hline Georgia & $9,687,653$ & $38,954,859$ & - & $1,124,460$ & - & 2.89 & 22.4 & $\$ 37.80$ & - & $\$ 7,438,301$ & $\$ 7,438,301$ \\
\hline Illinois & $12,830,632$ & $12,527,570$ & - & $1,489,270$ & - & 11.89 & 22.4 & $\$ 37.80$ & - & $\$ 9,851,520$ & $\$ 9,851,520$ \\
\hline Indiana & $6,483,802$ & $43,971,137$ & - & 752,584 & - & 1.71 & 22.4 & $\$ 37.80$ & - & $\$ 4,978,344$ & $\$ 4,978,344$ \\
\hline Kentucky & $4,339,367$ & $75,286,754$ & - & 503,677 & - & 0.67 & 22.4 & $\$ 37.80$ & - & $\$ 3,331,820$ & $\$ 3,331,820$ \\
\hline Maine & $1,328,361$ & $148,404,616$ & $1,430,000$ & 123,962 & $0.96 \%$ & 0.08 & 27.9 & $\$ 33.27$ & $\$ 10,354,694$ & $\$ 897,612$ & $\$(9,457,081)$ \\
\hline Maryland & $5,773,552$ & $24,643,818$ & - & 670,144 & - & 2.72 & 22.4 & $\$ 37.80$ & - & $\$ 4,433,005$ & $\$ 4,433,005$ \\
\hline Massachusetts & $6,547,629$ & $55,928,669$ & 250,000 & 692,702 & $0.45 \%$ & 1.24 & 24.6 & $\$ 48.73$ & $\$ 2,339,200$ & $\$ 6,481,471$ & $\$ 4,142,271$ \\
\hline Michigan & $9,883,640$ & $277,960,651$ & 490,000 & 883,115 & $0.18 \%$ & 0.32 & 29.1 & $\$ 42.53$ & $\$ 4,737,930$ & $\$ 8,539,053$ & $\$ 3,801,123$ \\
\hline Minnesota & $5,303,925$ & $39,181,626$ & - & 615,634 & - & 1.57 & 22.4 & $\$ 37.80$ & - & $\$ 4,072,420$ & $\$ 4,072,420$ \\
\hline Missouri & $5,988,927$ & $11,322,763$ & - & 695,143 & - & 6.14 & 22.4 & $\$ 37.80$ & - & $\$ 4,598,373$ & $\$ 4,598,373$ \\
\hline New Hampshire & $1,316,470$ & $77,720,574$ & 420,000 & 115,928 & $0.54 \%$ & 0.15 & 29.5 & $\$ 50.40$ & $\$ 4,882,752$ & $\$ 1,347,736$ & $\$(3,535,016)$ \\
\hline New Jersey & $8,791,894$ & $16,806,386$ & - & $1,020,488$ & - & 6.07 & 22.4 & $\$ 37.80$ & - & $\$ 6,750,526$ & $\$ 6,750,526$ \\
\hline New York & $19,378,102$ & $305,685,731$ & $1,903,000$ & $1,871,400$ & $0.62 \%$ & 0.61 & 26.9 & $\$ 38.83$ & $\$ 15,543,598$ & $\$ 15,285,487$ & $\$(258,111)$ \\
\hline North Carolina & $9,535,483$ & $84,977,529$ & - & $1,106,797$ & - & 1.30 & 22.4 & $\$ 37.80$ & - & $\$ 7,321,463$ & $\$ 7,321,463$ \\
\hline Ohio & $11,536,504$ & $87,616,491$ & 385,000 & $1,011,519$ & $0.44 \%$ & 1.15 & 29.7 & $\$ 39.07$ & $\$ 3,484,421$ & $\$ 9,154,697$ & $\$ 5,670,276$ \\
\hline Pennsylvania & $12,702,379$ & $278,622,099$ & 465,000 & $1,474,383$ & $0.17 \%$ & 0.53 & 22.4 & $\$ 36.00$ & $\$ 2,929,500$ & $\$ 9,288,615$ & $\$ 6,359,115$ \\
\hline Rhode Island & $1,052,567$ & $6,019,295$ & - & 122,173 & - & 2.03 & 22.4 & $\$ 37.80$ & - & $\$ 808,174$ & $\$ 808,174$ \\
\hline Tennessee & $6,346,105$ & $65,814,848$ & - & 736,601 & - & 1.12 & 22.4 & $\$ 37.80$ & - & $\$ 4,872,619$ & $\$ 4,872,619$ \\
\hline Vermont & 625,741 & $108,881,278$ & $3,200,000$ & 45,996 & $2.94 \%$ & 0.04 & 35.4 & $\$ 34.57$ & $\$ 30,566,151$ & $\$ 439,355$ & $\$(30,126,796)$ \\
\hline Virginia & $8,001,024$ & $71,216,930$ & - & 928,690 & - & 1.30 & 22.4 & $\$ 37.80$ & - & $\$ 6,143,286$ & $\$ 6,143,286$ \\
\hline West Virginia & $1,852,994$ & $125,961,220$ & - & 215,080 & - & 0.17 & 22.4 & $\$ 37.80$ & - & $\$ 1,422,752$ & $\$ 1,422,752$ \\
\hline Wisconsin & $5,686,986$ & $154,493,465$ & 650,000 & 480,653 & $0.42 \%$ & 0.31 & 30.8 & $\$ 37.17$ & $\$ 5,806,053$ & $\$ 4,293,378$ & $\$(1,512,675)$ \\
\hline United States & $308,745,538$ & $2,152,994,723$ & $9,268,000$ & $32,460,105$ & $0.43 \%$ & 1.52 & 24.7 & $\$ 39.54$ & $\$ 81,467,642$ & $\$ 247,981,361$ & $\$ 166,513,719$ \\
\hline
\end{tabular}

${ }_{1}^{1}$ This is determined by first multiplying the population by 2.3 (oz) to determine the total syrup consumption and then dividing this figure by the average production per tap for that state.

2 These figures are determined by dviding the number of taps reported for each state in the 2010 NASS Maple Syrup Crop Report by the number of potential taps based on the FIA data. 
technologies along the southern and western edges of red and sugar maples' ranges. If some producers adopt the latest technologies and are able to achieve economic yields of at least $32 \mathrm{oz}$. (946 ml) of syrup per tap, these success stories could entice others to get started.

As a nation, the U.S. only taps $0.39 \%$ of all sugar and red maples growing in the eastern half of the country. In order to supply the average citizen with $2.6 \mathrm{oz}$. $(76.9 \mathrm{ml})$ of "locally produced" U.S. syrup, it would have to add roughly 23 million taps, thereby increasing the utilization rate to $1.52 \%$. The economic impact of doing so would be USD167 million, increasing the size of the maple industry from USD 81 million to USD 248 million. However, to facilitate this growth, the U.S. would have to either stop importing syrup from Canada and/or increase average syrup consumption. It is highly unlikely that Americans will stop buying Canadian syrup, especially if it is relatively inexpensive and readily available in grocery stores. Thus, in order to increase consumption of locally produced maple syrup, U.S. producers should invest in strategic marketing campaigns that capitalize on the increasing interest in local, healthy food.

\section{Limitations and Drawbacks of These Analyses} It is important to understand the limitations of these analyses and why they are both unrealistic scenarios. For the first question, it is highly unlikely that any state will build its maple industry to the same status that Vermont has. Maple production is strongly tied to cultural heritage and Vermont has made a dedicated effort over the last century to build its reputation and brand itself as "the place for maple" in the U.S. So while Vermont presents a upper limit for what is possible to achieve in other states, it is highly unlikely that any other state will ever tap the same percentage of its trees as Vermont does.

It is also impractical to assume that the maple syrup produced within a state's borders is the only maple syrup residents of that state will consume. Since most people buy their food at grocery stores and it is difficult for small, local producers to gain access to these markets, many residents will continue to buy imported syrup. Thus, the average syrup consumption in each state must be higher than the national average of $2.6 \mathrm{oz} .(76.9 \mathrm{ml})$ per person in order to account for the additional syrup coming from out of state. On the other hand, not all the syrup that sugarmakers produce is sold to residents of their state. Many producers have extensive mail-order businesses, sell directly to tourists, or sell to restaurants and gift shops that cater to out-of-state tourists. Furthermore, the commercial-grade syrup that is produced at the end of the season is almost always sold to large bottling and distribution companies in Vermont and New Hampshire. Since a portion of the syrup produced in any state would be sold and consumed elsewhere, the per capita consumption among residents of that state could be lowered. Without knowing the magnitude of these variables, it is not possible to know the effect on necessary per capita consumption levels.

Furthermore, having a target consumption level of only $2.6 \mathrm{oz}$. $(76.9 \mathrm{ml})$ per person is likely to underestimate the actual syrup consumption levels in states that produce maple syrup. Many producers are happy to share their products with friends, family members, and neighbors at a reduced price or free of charge, so naturally these people consume more syrup than they otherwise would. Even for people with no relation to a sugarmaker, there is still a more readily accessible supply of pure maple. The prevalence of maple products being sold through sugarhouses, roadside stands, farmers' markets, community supported agriculture operations (CSAs), producer-operated pancake houses, and other venues for local food tends to increase the average per capita consumption of pure maple in regions where it is produced.

In fact, historical research by the U.S. Forest Service found that only $1.9 \%$ of households outside the maple-producing region had purchased pure maple syrup over a 12 -month time frame versus $11.2 \%$ of households within maple producing states (Sendak, 1978). Therefore, the $2.6 \mathrm{oz}$. $(76.9 \mathrm{ml})$ per person average consumption likely presents a minimum level that each producing state could easily achieve 
by supplying syrup from its own trees. Perhaps a more realistic estimate of syrup consumption in maple-producing states is $6 \mathrm{oz}$. $(177 \mathrm{ml})$ per person, the level currently achieved in Quebec (Agriculture and Agri-Food Canada, 2006). However, since many residents will continue to purchase syrup from grocery stores that has been imported from outside the state or country, a 2.6 oz. $(76.9 \mathrm{ml})$ per capita consumption of maple syrup produced within a state's borders may be a realistic target for many states.

It is also important to consider the impact of yield per tap in conducting these analyses. The volume of syrup produced varies greatly from year to year, depending primarily upon the weather patterns and sap collection technologies that are used. New vacuum tubing systems can result in yields as high as 0.5 gallons of syrup per tap (64 oz. or 1,893 ml), whereas traditional bucket systems may only yield 0.1 gallons per tap (12.8 oz. or $379 \mathrm{ml})$. It is possible that average yields per tap could increase as more producers adapt the latest technologies with vacuum tubing. If this were to happen, either fewer taps would be needed to produce the same amount of syrup, or consumption would have to rise in order to keep pace with the additional syrup output.

Finally, the economic impact figures presented here only account for the farm-gate syrup sales of individual producers. They do not include the economic activities of bottling companies who purchase bulk syrup, package it into retail-size containers, and market it throughout the U.S. and beyond. Nor do they factor in the economic impacts of building sugarhouses and manufacturing and selling all the equipment necessary to produce maple syrup. Given all the additional economic activity that is involved with maple production, the economic impact figures provided in these tables grossly underestimate the true impact of expanding the maple industry. Determining the full economic impact of syrup production would require significant additional research and is outside the scope of this paper.

\section{Conclusion: Marketing Must Keep up with Production}

The fate of the global economy, coupled with the marketing efforts of the maple industry, will have a strong influence on the overall production and consumption of pure maple syrup. Production has spiked in recent years and is likely to continue to grow, so the maple industry will have to be more aggressive in its marketing and promotion efforts in order to keep demand in line with supply and prices stable. Per capita consumption of pure maple syrup in the U.S. is currently very low, so there is tremendous room for expansion, especially in the growing niche markets for local and healthy foods. The average American consumes about 2.6 ounces $(76.9 \mathrm{ml})$ of syrup in one pancake breakfast, so clearly there is room for growth. One of the keys will be educating consumers about the differences between pure maple syrup and its artificial competitors and convincing them that pure maple syrup is worth the extra cost.

Maple syrup is produced commercially only in the eastern U.S. and Canada, yet there is a growing worldwide demand for pure maple products, especially once people are exposed to them. Marketing efforts have been extremely successful in other countries, as Canadian exports to Japan rose by $252 \%$ between 2000 and 2005 once the Federation of Maple Producers in Quebec initiated a marketing campaign there (Agriculture and AgriFood Canada, 2006). Markets have also been growing steadily in western Europe, as Canadian exports to Denmark and Switzerland each grew by more than $100 \%$ over the same time period. Even in the U.S., where most people should already know about pure maple syrup, marketing efforts often lead to dramatic increases in sales. For instance, the New York State Maple Producers Association initiated Maple Weekend, a statewide event where sugarmakers open their doors during the last two weekends in March every year. This event has grown steadily since it began in the 1990s and now accounts for over USD750,000 in sales among the over 100 participating producers during a four-day period (H. Thomas, personal communication, January 21, 2011). Vermont, Maine, Pennsylvania, and others have since adopted similar 
campaigns for their states. Despite these successes, only a small fraction of maple producers in the U.S. currently participate in this type of event.

If the maple industry continues to expand and supply outpaces demand, it should not be viewed as an overproduction problem, but rather an undermarketing problem. There is overwhelming evidence that investments in marketing pay off in terms of increased consumption of pure maple products. Per capita consumption has nearly tripled in the U.S. over the past 35 years, yet it is still quite low at less than $3 \mathrm{oz}$. ( $89 \mathrm{ml}$ ) per person, so more efforts should be put into marketing pure maple syrup as the local, healthy sugar in the regions where it is produced. Moreover, since maple syrup is only produced in eastern North America and yet has a growing worldwide demand, there is a tremendous opportunity to supply this high-value crop to international markets. It is up to the entire maple industry to work together - as they have in Quebec (Gagné, 2008), New York, Vermont, and elsewhere - to move the industry forward in a positive direction. In particular, further consumer research is necessary to determine the current and potential demand for maple syrup on a state-level basis throughout the U.S. Increasing both production and marketing efforts will provide more people locally and throughout the world with pure maple products while maintaining profitable prices for producers.

\section{Acknowledgments}

The authors would like to thank Charles Barnett and Elizabeth LaPoint of the U.S. Forest Service FIA Program for providing the raw data on maple tree abundance, and Jeremy Farrell of Rensselaer Polytechnic Institute for his assistance in analyzing the data.

\section{References}

Agriculture and Agri-Food Canada. (2006). Canadian maple products, situations and trends 2005-2006. Ottawa, Canada: Author. Retrieved from http://www.agmrc.org/media/cms/maple e 4143489AA9055.pdf

Bechtold, W., \& Patterson, P. (2005). The enhanced forest inventory and analysis program: National sampling design and estimation procedures. General Technical Report SRS-80. Asheville, North Carolina: U.S.

Department of Agriculture, Forest Service, Southern Research Station.

Buchheit, J. K., Carver, A. D., Zaczek, J. J., Crum, M. L., Mangun, J. C., Williard, K. W. J., \& Preece, J. E. (2004). Economic feasibility of commercial maple syrup production in Illinois. In D. A. Yaussy, D. M. Hix, R. P. Long, \& P. C. Goebel (Eds.), Proceedings, 14th Central Hardwood Forest Conference (116-121).

Gen. Tech. Rep. NE-316. Newtown Square, Pennsylvania: U.S. Department of Agriculture, Forest Service, Northeastern Research Station. Available from http://treesearch.fs.fed.us/pubs/22698

Chamberlin, M. (2008). Feasibility study for maple center at NYS Fairgrounds. Unpublished report prepared for the New York State Maple Producers Association.

Chapeskie, D., Wilmot, T., Chabot, B., \& Perkins, T. D. (2006). Maple sap production-tapping, collection, and storage. In R. B. Heiligmann, M. R. Koelling, \& T. D. Perkins (Eds.), North American maple syrup producers manual (2nd Edition) (pp. 81-117). Columbus, Ohio: The Ohio State University Press.

Churchill, C. (2008, April 30). Untapped resource: A new effort may take the stickiness out of reaching more sugar maples. Albany Times Union.

Clifford, S. (2010, October 10). Wal-Mart to buy more local produce. New York Times. Retrieved from http://www.nytimes.com/2010/10/15/business/ 15walmart.html?pagewanted $=$ all

Dravis, S. (2008). Shortfall drives prices higher. The Maple News, 7(5), 1.

Dravis, S. (2009). Industry expansion needed. The Maple News, 8(2), 1.

Farrell, M. L., \& Stedman, R. C. (2009). Survey of NYS maple producers: Report to the steering committee of the Lewis County Maple Symp Bottling Facility. Ithaca, New York: Department of Natural Resources, Cornell University. Retrieved from http://maple.dnr. cornell.edu/pubs/MapleProducerSurvey2009.pdf

Gagné, I. (2008, May 30). Maple syrup production in Quebec: Farmer self-determination for market control. Regoverning Markets Innovative Policy series. Retrieved from http://www.regoverningmarkets.org/en/ resources/global/innovative policy c2 rd 2 canada maple syrup production in quebec farmer self determination for market control 
Hoyum, K. (2010, September 1). One sweet idea: Michigan could one day be the world's leading producer of maple syrup. Upper Peninsula's Second Wave. Retrieved from http://up.secondwavemedia. com/features/maplesyrup090110.aspx

Hinrichs, C. C. (1998). Sideline and lifeline: The cultural economy of maple syrup production. Rural Sociology, 63(4), 507-532. http://dx.doi.org/10.1111/j.1549_ 0831.1998.tb00690.x

Karkos, T. (2011, February 3). Legislator wants Maine to expand maple syrup industry. Bangor [Maine] Daily News. Retrieved from http://new.bangordaily news.com/2011/02/03/politics/legislator-wantsmaine-to-expand-maple-syrup-industry/

Litten, K. (2011, January 3). An untapped market: Maple syrup producer says Connecticut could boost output 20-fold in next decade. Republican American [Waterbury, Connecticut]. Retrieved from http://www.rep-am.com/articles/2011/01/03/ news/local/530768.txt

Schwaner-Albright, O. (2009, March 11). As maple syrup prices rises, New York leaders see opportunity. New York Times, B3.

Sendak, P. E. (1978). Consumer preferences for graded maple syrup. Forest Service Research Paper NE-402. Washington, DC: Government Printing Office.
Skinner, C. B., DeGaetano, A. T., \& Chabot, B. F. (2010). Implications of twenty-first century climate change on Northeastern United States maple syrup production: Impacts and adaptations. Climatic Change, 100(3-4), 685-702. http://dx.doi.org/ 10.1007/s10584-009-9685-0

U.S. Census Office. (1860). Statistics of agriculture, eighth census. Washington, DC: Government Printing Office.

U.S. Department of Agriculture, Forest Service. (2010). Forest Inventory Data Online (FIDO) (Version 1.4.2)

[Database]. Retrieved from http://apps.fs.fed.us/fido/

U.S. Department of Agriculture National Agricultural Statistics Service (USDA NASS). (June 11, 2010). Crop production report: Maple syrup 2010. Washington, DC: Author. http://www.nass.usda.gov/ Statistics by State/New England includes/ Publications/Special Reports/0610maple.pdf

Wanamaker, T. (2009, March 26). State creates Maple Task Force to enhance industry. Watertown [New York] Daily Times, B2.

Whitcomb, K. (2009, April 16). Proposal could open state land for sugaring. Bennington [Vermont] Banner, Article \#12154193. 
Journal of Agriculture, Food Systems, and Community Development ISSN: 2152-0801 online www.AgDevJournal.com 